\title{
As armadilhas da memória: história e mito em Emir Rodríguez Monegal
}

Pablo Rocca

\section{Territórios da memória e do esquecimento}

Em seu clássico estudo de 1975, Philippe Lejeune afirma que um texto é considerado autobiográfico quando ocorre um pacto entre o narrador-protagonista e o receptor. Apesar disso, desde os relatos de André Gide - que Emir Rodríguez Monegal conhecia e admirava - a ficção romanesca gerou uma nova aliança, ou seja, a do "pacto fantasmagórico". Esse pacto consiste na possibilidade de ler o que está por trás da vestimenta ficcional e encontrar-se com o fantasma do autor, com o espectro de sua identidade e o ostensivo rastro de seus passos (LEJEUNE, 1975, p. 165 e seg.).

O modelo de Gide é um dos paradigmas possíveis para se pensar o relato autobiográfico escrito literalmente à beira da morte por um dos maiores críticos literários da América Latina em meados do século XX: o uruguaio Emir Rodríguez Monegal (1921-1985). Esse episódio não ocorreu apenas porque está situado no final da carreira e da vida de Monegal e, tampouco, porque foi o último grande texto que redigiu quando soube, em 1985, que o câncer em breve o levaria (como confessou em entrevista a seu antigo amigo e rival, Ruben Cotelo), mas porque, ciente de seu propósito, assume-se como objeto e sujeito de sua própria narrativa. Além disso, ele se dispôs a escrever um relato autobiográfico que seria o primeiro volume, de um total de sete, que a morte lhe impediria escrever:

Em 1943, pensei em começar a escrever [minhas memórias], mas aos vinte e dois anos não se tem memória. Comecei a encher os cadernos com notas. Procurei esses cadernos e encontrei materiais muito bons. Escrevi durante dois meses, entre o hospital e minha casa. O primeiro tomo está terminado. [...] Comecei a escrever no hospital, à mão, em uma agenda. Comecei e não podia parar. Quando não escrevia, a cabeça continuava escrevendo, até mesmo enquanto dormia. Era uma necessidade vital. (COTELO, 1985, p. 34).

Nessa entrevista, confessou ter avançado muito no segundo tomo, dedicado à sua experiência em Marcha, assim como no terceiro, onde narraria sua estadia inicial na Inglaterra. No entanto, nada, nem um fragmento chegou a ser publicado até o momento. Joaquín Rodríguez Nebot, segundo filho do autor, disse-nos que em 1991, nos últimos dias de vida, seu pai havia redigido várias páginas em um caderno que se perdeu. O último tomo, segundo declaraçôes do próprio Rodríguez Monegal, seria intitulado, joyceanamente, Epifanias. Neste, pensava em incluir "episódios de minha vida que jamais haviam me contado" e "muitas histórias de minha família [que] eram mentiras" (COTELO, 1985, p. 37). Sua morte ocultou a resolução do enigma. Contudo, as páginas do primeiro e único tomo, Las formas de la memoria. Los magos (1989), discorrem sobre os dezesseis primeiros anos de sua vida (1921-1937). Nesse livro, publicado no México com um prólogo de Haroldo de Campos, encontram-se algumas pistas que nos possibilitaram investigar e achar algumas respostas.

O relato autobiográfico tem início na "obsessiva cidade de Melo", uma pequena cidade do noroeste uruguaio, situada a noventa quilômetros da fronteira com o Brasil, até o retorno, do Rio de Janeiro a Montevidéu, do eu-narrador-personagem e sua família. Melo, local onde nasceu e passou apenas dois anos de vida, mas que sempre recordava por meio dos mais velhos; Montevidéu, onde viveu desde seus primeiros anos; Porto Alegre e Rio, onde passou três temporadas permanecendo, na última, em duas ocasiōes e durante mais tempo do que na primeira. O Brasil, como é possível verificar, ocupa um espaço central nesse relato.

A narrativa é composta por dois níveis que se superpõem. Um deles corresponde ao ciclo familiar e adolescente do eu-narrador, eixo de toda a ação; o outro se fragmenta em dezenas de partes, como uma 
narrativa cinematográfica organizada segundo a técnica presente em Rashomon, de Akira Kurosawa. De fato, ao tomar consciência, por meio de uma tradução argentina, de que Rashomon era um velho conto, de 1915, escrito por Ryunosuke Akutagawa, no qual havia se inspirado o diretor japonês, Rodríguez Monegal aproveitou para esboçar um comentário sobre a narrativa fílmica que pode ser utilizado para compreender sua própria técnica: "O film não buscava constatar a verdade: queria apenas mostrar que isto é impossível, uma vez que todos mentem, inclusive contra si mesmos e antes de conferir-se um papel negativo" (MONEGAL, 1954, p. 15).

Por essa razão, para a negação da verdade absoluta e a hierarquização da verdade subjetiva, este segundo nível de Las formas de la memoria... tem uma importância central, subdividindo-se em uma galeria de personagens: pais, avós, tias, primos, vizinhos, companheiros de colégio, amigos de família, personagens históricos que em algum momento aproximam-se dele e conhecidos ocasionais que deixaram marcas em sua memória.

Quase não se constatam excessos ou embaraços nessa meia centena de seres que convivem em menos de duzentas páginas. Sua pessoal e breve comédia humana não apresenta o risco da fadiga, exceto em duas circunstâncias: quando se refere à sua tia-avó, uma espécie de fada madrinha do garoto, que sempre lhe concede dinheiro para doces, presentes e, desde cedo, livros; a mulher que lhe ensinou a ler e a escrever, a primeira com quem praticou rituais eróticos (carícias e beijos em sua enorme papada); e também quando repete, reiteradamente, as várias debilidades e precocidades do eu-protagonista.

Cada personagem tem o seu lugar, o seu tempo e a sua oportunidade. Aqueles que se sobressaem servem para unir os dois níveis. Por meio deles se recupera uma vida dupla, ou seja, a que lhes confere certa autonomia e a que fomenta suas impressóes e até os atos do próprio narrador. Alguns funcionam como tipos, seja representando uma classe determinada, ou uma ideia. Nesta categoria, incluem-se, por exemplo, umas vizinhas melenses que o narrador evoca, através do olhar do menino, imagens estereotipadas do beatério, a intriga e a maledicência popular. Surge, ainda, o "tio Bonilla", avarento e cruel, proprietário do hotel $\mathrm{ABC}$ em Montevidéu, lugar onde vivia com sua numerosa família. Há, também, os adultos que desejam apresentá-lo à homossexualidade: um, em Montevidéu, quando o eu-narrador tem cinco anos, e o outro no Rio, alguns anos depois (MONEGAL, 1989, p. 40 e 117). ${ }^{1}$ Outros garantem seu espaço na narrativa em virtude de seu contorno definido. É o caso de "Papá Viejo", ou seja, seu avô materno Cándido Monegal, verdadeiro pioneiro da imprensa do interior do Uruguai, com seu jornal El Deber Cívico (Melo, 1887-1984), fomentador da cultura naquela remota região, muito mais profícuo do que seu neto admite reconhecer. Este o evoca como uma figura quase mitológica, de barbas brancas, traje completamente negro, porte "alto e firme", "homem estoico e taciturno" (MONEGAL, 1989, p. 15).

Há, ainda, três membros da família Monegal que se destacam por suas características particulares e pelas imagens e símbolos que evocam no menino-adolescente. Dois deles quase gêmeos - os tios Monegal: José (Pepe) e Casiano (Cacho) - e o terceiro, seu pai, Manuel Rodríguez Moleón. Os três têm em comum a boemia, a predileção por "um líquido amarelo, a cachaça" e, sobretudo, pelo exemplo sedutor da transgressão à norma.

Quanto ao último, "homem bonito" e elegante, segundo o eu-narrador, era filho de um galego que se instalou no Paraguai - onde nasceu Manuel Rodríguez - e, depois, no Mato Grosso, onde instalou uma fábrica de cerveja e guaraná que lhe rendeu uma fortuna (MONEGAL, 1989, p. 71). "Papá" vivia em Montevidéu com a constante nostalgia do Brasil, onde voltou frequentemente, carregando consigo a sua família e a sua eterna esperança de regresso definitivo. Esse desejo finalmente se cumpriu, mas deixando a mãe de Emir por outra mulher. Aos vinte anos, quis demonstrar a seu pai, empreendedor e severo, que podia fazer fortuna e também meter-se na selva brasileira. Em vez de dinheiro, encontrou ali a fome, a malária e uma piorreia "que lhe consumiu os dentes". Rodríguez Moleón é retratado como o protótipo do aventureiro. Sua ousadia e peripécias selvagens somente se assemelham às que padeceu Ernesto "Che" Guevara na selva boliviana (MONEGAL, 1989, p. 86). Todo o capítulo II ("O feitiço de Corumbá”) é dedicado à hipérbole desse herói em particular. Não há outros Rodríguez em 
cena, salvo uma tia que quase não se vê e uma mera referência a esses avós que o eu-narrador-protagonista nunca chegou a conhecer. ${ }^{2}$

A família Monegal ocupa a maior parte dessas memoráveis notas. Todavia, não é apresentada como a quintessência da perfeição. Entre eles figuram sujeitos que se converteram em objeto de rancor do narrador, embora sem a demolidora fúria com que Rodríguez Monegal tratou seus opositores no campo literário.

Nesse sentido, caberia postular que esse volume isolado pode ser mais bem definido como "antimemórias", não no sentido fragmentário e deliberadamente incompleto com que André Malraux catalogou as suas, mas no que se refere à forma com que a escritura resiste a enaltecer o passado, em todas e em cada uma de suas instâncias. Mesmo assim, é importante considerar, como visto anteriormente, que Manuel Rodríguez tem suas exceções. Se partirmos desse pressuposto, podemos notar que sua cidade natal é três vezes, em cinco páginas, caracterizada como medíocre (MONEGAL, 1989, p. 13, 14 e 18). Essa forma não se assemelha à evocação de um espaço áureo que, em diversos discursos, jamais se deixa de amar, como demonstra Ángel Rama ao narrar as lembranças de sua mãe no seu romance Tierra sin mapa (1960). Também não se parece ao reduto de exotismo presente nas narrativas rurais da primeira metade do século XX, nem à deslumbrante Macondo. Ao contrário, apenas consegue atingir a categoria de "poeirenta e asfixiante vila" (MONEGAL, 1989, p. 42).

As jornadas em Porto Alegre e no Rio de Janeiro não somente lhe aprisionaram como também lhe ocasionaram algumas moléstias. Já os exaltados encantos de Montevidéu também não o impediram de recordá-la como uma "cidade úmida e fria que chega a calar os ossos no inverno", na qual Rodríguez Moleón sofria a ausência do "maravilhoso" Brasil, onde havia constituído uma outra cidade, Corumbá, cujo nome era "tão ressonante que sintetizava toda a magia do mundo" (MONEGAL, 1989, p. 33 e 69).

É uma narrativa que nunca poupa críticas aos defeitos alheios, nem se refugia em afetos seguros, mas baixa a guarda quando caracteriza o menino que foi o narrador, carregando nas tintas de sua fragilidade física de miserável e mimado: "eu era enfermo e impressionante"; "padecia de uma bronquite asmática que não me dava trégua"; "a junta familiar decidiu que eu era demasiado delicado para a escola pública e que era melhor que ficasse em casa"; "precoce ermitão [...], eu tinha confinado minha bronquite crônica" (MONEGAL, 1989, p. 31 et passim). "Esse patinho feio que eu era quando criança [...] tonto, eu havia me acostumado a ser tonto [...] era, pois, enfermo, sonhador e um pouco além"; sofria de "uma afonia tão persistente que praticamente me tornava inaudível" (MONEGAL, 1989, p. 51 e 122). Tudo se desfazia diante de "meu rosto de menino gordinho, tímido e moreno"; tudo se resumia a um caráter "indolente e algo molenga como um Oscar Wilde adolescente" (MONEGAL, 1989, p. 136 e 144). Era um "avestruz", reiteradíssimo sinônimo para um desvalido garoto, protegido por uma família singular e numerosa, que o estimulara ao prazer estético, ao prazer da leitura, ao precoce e fanático deleite do cinema, da pintura e da poesia. Esta última foi soltando-se, como aderências menores ou circunstanciais, de um coquetel composto pela feiura, timidez e inteligência do garoto-protagonista. Sua vida de clausura proporcionou-lhe diversas horas mortas nas quais consumiu filmes, revistas, livros até descobrir, em 1935, alguns breves textos que mudariam sua vida:

[...] ao adentrar o quarto de minha tia Nilza, comecei a folhear uma revista feminina que ela costumava comprar, El Hogar, e entre fotos de senhoras da melhor sociedade argentina que luziam suas peles em Buenos Aires, ou se refrescavam em Mar del Prata, encontrei uma seção bibliográfica, sobriamente intitulada "Livros e Autores Estrangeiros", assinada por um tal de Jorge Luis Borges. Uma mera folheada me revelou o que eu precisamente andava buscando há muitos anos: notícias críticas sobre a literatura contemporânea. (MONEGAL, 1989, p. 158).

Seu avô havia sido jornalista e editor, “o homem mais importante da pequena cidade de Melo"; seus tios maternos eram escritores; seu pai havia se formado nos Estados Unidos, onde adquiriu o porte de um elegante intelectual, embora todos, e cada um deles, sempre apareçam, nas páginas de Rodríguez Monegal, acompanhados de um adjetivo piedoso: "interiorano", "provinciano", "boêmio" e, inclusive, 
para os três últimos, o de "bêbado". O mais exemplar, aquele que desde o princípio havia se dado conta de que nem o álcool nem as noitadas eram bons conselheiros para a disciplina do trabalho seria o eu-narrador-protagonista. O intelectual precoce e sério está em plena construção, ou melhor, em plena autoconstrução, nesse primeiro tomo, onde menciona que "sem querer ia preparando-me para minha futura carreira”. É nele que se concentraria uma capacidade singular de saltar do ínfimo e trivial, do interiorano, em síntese, às esferas do debate e da circulação da cultura mais elevada, porque ao contrário de seus antecessores - condenados a uma comiserativa marginalidade - percebeu prontamente a necessidade de traçar para si "um plano, um projeto" (MONEGAL, 1989, p. 36).

Um fantasma ronda a autobiografia de Rodríguez Monegal. Se perseguirmos obsessivamente todas as pistas biográficas de seus antepassados, a mãe do narrador-protagonista aparecerá retratada como uma pessoa dependente de suas irmãs e primas, falando da "obsessiva Melo", oferecendo pequenos cuidados ao garoto - geralmente impostos - ou a partir da imagem de seu marido, a quem estabeleceu limites e condições que o deixaram frustrado. Além disso, nunca mencionará como seus pais se conheceram, nem onde. Não haverá sinal algum de que Rodríguez Moleón tenha pisado um dia sequer em Melo. Tal omissão é no mínimo curiosa ao lembrarmos de que o narrador informa que sua família mudou-se para Montevidéu quando ele ainda não havia completado dois anos, o que torna esta mudança incompreensível, visto que, em consequência disso, a situação econômica dessa família de classe média baixa compromete-se, ao invés de melhorar. Esta "parte da história nunca era contada com detalhe. Havia afirmações vagas, silêncios e lacunas, como se tudo fosse já amplamente conhecido e não valesse a pena falar muito a respeito" (MONEGAL, 1989, p. 17).

Rodríguez Monegal havia notado, com suas detidas leituras sobre psicanálise - da qual se nutriu para escrever numerosas biografias, em especial as de Horácio Quiroga e de Jorge Luis Borges -, "a repugnância da memória em evocar recordações que se encontram associadas a sensações adormecidas cuja evocação haveria de renovar tais sensações" (FREUD, 1968, p. 77). Quase axiomaticamente, ainda que sem citá-la de forma expressa, utilizou esta perspectiva em sua biografia de Quiroga, quando assinalou as diferentes artimanhas do autor rioplatense em sua correspondência particular, a fim de evitar as referências à insólita cadeia de suicídios que marcaram sua vida, ou a morte acidental de Federico Ferrando, da qual foi responsável o próprio Quiroga (MONEGAL, 1968).

O mesmo ocorreu com Rodríguez Monegal e a história de seu pai. No capítulo inicial de Las formas de la memoria..., que ocupa a metade do livro, há apenas três referências passageiras a "papá". Ainda que a segunda parte esteja integralmente dedicada a Manuel Rodríguez, sua história começará a fundirse com a do eu-narrador, quando relata a infância daquele e não, desde o começo de sua vida. Borges, ao contrário, é mencionado quatro vezes no primeiro capítulo e em doze ocasiōes ao longo de todo o volume, salvo o Apêndice, que lhe dedica por completo, a propósito de uma interpretação sui generis do conto "A outra morte" (El Aleph, 1949). Manuel Rodríguez Moleón pode ter sido "papá", mas o pai simbólico que Rodríguez Monegal quis, o que compulsivamente necessitou, e até de algum modo construiu, foi Jorge Luis Borges.

Contudo, antes mesmo desse acontecimento decisivo para Rodríguez Monegal e, também, para a crítica borgeana no Rio da Prata e, posteriormente, em qualquer parte, ocorreram ainda outros fatos somente sugeridos nas memórias do crítico. No Registro Civil da Intendência Municipal de Cerro Largo, no ano de 1921, encontra-se arquivada uma certidão de nascimento de número 297, onde se lê em suas passagens substanciais:

$\mathrm{Na}$ cidade de Melo, no dia três de agosto de mil novecentos e vinte e um, às dez e sete, diante de mim, Lisandro J. Saínz, oficial de estado civil da primeira seção do Departamento de Cerro Largo, comparece a senhora Hilda Monegal, de nacionalidade oriental, ${ }^{3}$ de vinte e dois anos, estado civil solteira, profissão trabalhos diversos, domiciliada nessa cidade declarando com o objetivo de que se inscreva no Registro Civil: que na rua 25 de maio, n. 791, no dia vinte e oito de julho último, às seis, nasceu uma criatura do sexo masculi- 
no que é filho natural da declarante e de pai desconhecido. Que é neto de linha paterna desconhecida, e por linha materna de Cándido Monegal [...] e de Paula Sorondo [...]. E que a expressa criatura recebeu o nome de Emir... (Intendência Municipal de Cerro Largo, Certidão de Nascimento n. 297, livro do ano 1921).

Em dezembro de 1985, pouco tempo depois do regresso fugaz de Emir Rodríguez Monegal ao Uruguai e há poucas horas da chegada da notícia de sua morte, um velho morador de Melo contou-me uma história de sangue que parecia ter saltado de um conto de Borges. Disse que, em torno de 1921, estava com uns amigos, de aproximadamente quinze anos como ele, conversando em uma esquina no centro do povoado, quando subitamente soaram dois ou três tiros por perto. Então, junto aos outros rapazes, correu até o lugar de onde haviam partido os estampidos e os gritos. Ali viu o corpo frio de um homem jovem.

Consegui encontrar informação sobre que o fato - nunca mencionado por Rodríguez Monegal em suas memórias nem em outro lugar que conheça - ocorreu em Melo, no dia 28 de fevereiro de 1921, às nove horas. Dois homens discutiram. Um deles chamava-se Casiano Monegal (o tio Cacho), de trinta e seis anos de idade; o outro era um engenheiro agrônomo dez anos mais novo: Héctor Fermín Suárez Saravia. O mesmo funcionário da Intendência Municipal que, alguns meses depois lavraria a certidão de nascimento de Emir Monegal, anotou:

[...] no dia primeiro de março de mil novecentos e vinte e um, às oito [...] diante de mim [...] comparecem o senhor Amaro L. Vieira, nacionalidade oriental, de quarenta e quatro anos, estado civil casado, profissão comerciante [...] e o senhor Genaro Zavala García, nacionalidade oriental, de vinte e seis anos, estado civil solteiro, profissão comerciante [...] declarando que às nove horas do dia de ontem e na rua 25 de agosto, esquina com a rua Solís, faleceu Héctor Fermín Suárez, do sexo masculino, nacionalidade oriental, profissão engenheiro agrônomo, em consequência de peritonite aguda causada por feridas de bala, segundo consta do atestado do doutor Miguel Argenzio, que se encontra arquivado. [...] Mesmo assim, consta que os declarantes são simples vizinhos do falecido. (Intendência Municipal de Cerro Largo, Certidão de Óbito n. 70, livro do ano 1921).

No jornal da família Monegal, El Deber Cívico, a edição próxima ao fato não informou do assassinato. Nem nas seguintes. Casiano Monegal esteve durante poucos meses, em 1921, na cadeia de Melo, fato que conhecemos por uma carta que escreveu dali a Barret Herrera, depositada no Arquivo Literário da Biblioteca Nacional, na coleção documental do pai deste último, o dramaturgo Ernesto Herrera. Nada menciona sobre o motivo de sua prisão nessa epístola. Outro documento, tampouco aludido em Las formas de la memoria..., completa o quebra-cabeça:

Em Montevidéu, no dia dezessete de março de mil novecentos e vinte e nove, às onze horas, diante de mim, Pedro López Arresgicor, oficial de estado civil da $3^{\text {a }}$ seção do departamento de Montevidéu, comparecem Hilda Monegal de Rodríguez, casada, oriental, de vinte e oito anos [...] e o senhor Manuel Rodríguez San Pedro, casado, paraguaio, de vinte e cinco anos, empregado e domiciliados ambos na Rua Sarandí 392, cuja identidade certificam os testemunhos de meu conhecimento que, ao final, subscrevem. Estes me declaram que no dia vinte e oito de julho de mil novecentos e vinte e um, na cidade de Melo (Depto. de Cerro Largo), nasceu uma criatura do sexo masculino, a quem foi dado o nome de Emir, como consta da certidão de nascimento expedida pelo secretário do Conselho da Administração do Depto. de Cerro Largo, à folha 149 e sob o n. 297, que apresentam e que se encontra arquivada e que reconhecem por ser seu filho natural de acordo com o artigo 233 do Código Civil. Aqui se faz constar que os declarantes contraíram matrimônio com data de vinte e sete de junho de mil novecentos e vinte e oito [...], como consta da certidão de casamento expedida pelo Diretor do Registro Civil que apresentam e que lhes é devolvida [...] (Intendência Municipal de Montevidéu, Certidão de Reconhecimento n. 14, livro do ano de 1929).

Com esse ato administrativo, Hilda Monegal subtrai cinco anos de sua vida. Com este recurso, consegue restituir sua honra manchada em 1921. Nesta última data havia declarado vinte e dois anos, informação correta, segundo se verifica na certidão de nascimento $\mathrm{n}^{\mathrm{o}} .61$ do Livro correspondente a 1899. Com a subtração posterior, fica com a mesma idade de seu marido e, sobretudo, com esse simula- 
cro consegue uma dupla legitimação: diante dele muda a primeira parte de sua história, fabricando uma gravidez adolescente ocorrida aos dezesseis anos e não aos maduros, ou menos cândidos, vinte e dois anos; diante da sociedade montevideana, na qual buscou refúgio para esconder a mancha, ostenta um filho nascido fora do casamento e, como um estrangeiro que "regressa" para tomar posse de sua paternidade e de sua mulher, legaliza a situação, quando a criança ainda não cumpriu os sete anos de idade.

Com a exumação desses documentos afloram outros indícios que podem ser reunidos como se fossem peças de um complexo quebra-cabeças que começa a mostrar um desenho completo, esse que Rodríguez Monegal não pode terminar. Somente assim se entendem certas referências esparsas. Como a que interpola em seu autorretrato, o eu-narrador-protagonista: "algo da tristeza dos guaranis ficou refletida nos traços de meu rosto vasco... A verdade é que por parentes que nunca conheci, os Suárez, chegaram-me algumas gotas de sangue índio e gaúcho” (MONEGAL, 1989, p. 89-90).

Somente com estas provas entende-se a avaliação sobre seu tio Casiano: "Cacho era para mim, então, não só o mais remoto como o mais insignificante dos membros... Passar-se-iam muitos anos antes que soubesse que havia desempenhado um papel decisivo em meu destino". Ou esta outra: "eu não acreditava em Cacho e sabia (ou sentia em meu interior de uma maneira que não era explicável com palavras) que Pepe valia mais... Demoraria mais vinte anos para descobrir que Cacho, e não Pepe, havia sido a pessoa mais importante em minha infância” (MONEGAL, 1989, p. 64 e 68).

Uma nova dimensão "perspectivista e cruel" dessa versão da "outra morte", a de Suárez, chega com a última forma da memória, quando nas palavras seguintes do texto memorialista evoca-se a véspera de Reis de 1926. Nesta noite, a criança-protagonista de cinco anos espera receber seus presentes e especula ansiosamente sobre eles:

Mas, mamãe, que me escutava em silêncio, interrompeu-me para dizer que era inútil, que os Reis Magos não existiam, que eram os pais que compravam os brinquedos como uma forma de perpetuar uma graciosa tradição... Mamãe abundou em explicações: não havia chegado o dinheiro que Papá Viejo lhe mandava regularmente. (MONEGAL, 1989, p. 178).

Diante da certeza da outra morte, a sua, que tenta prorrogar com a escrita de suas memórias, Rodríguez Monegal interpreta que dessa lição dolorosa havia tirado sua "flecha de metal. Sobre ela construiria aos poucos minha carreira".

Os Magos revelaram a fragilidade econômica de mamãe, que dependia exclusivamente de um dinheiro que mandava algo irregularmente Papá Viejo... Pouco a pouco [...] fui inventando a mim mesmo. Esse foi o presente imperecível que me fizeram os Magos naquela longa noite de 5 para 6 de janeiro de 1926. Somente quinze anos mais tarde, em outra longa noite de vigília que passamos, mamãe e eu, no [Hotel] ABC, haveria de inteirar-me dos pormenores de minha infância que explicavam este incidente dos Reis Magos. Até então, eu, que tantas vezes me perguntei como poderia ter ocorrido aquele horror, não me dei conta de que a única pergunta que nunca fiz (ou me fiz) era: Onde estava papai então? (MONEGAL, 1989, p. 179).

Uma vez resolvido este enigma, aos vinte anos, Rodríguez Monegal seria arrastado pela vertigem de um reconhecimento que, entre outros assombros, o aparentava, por linhagem materna de seu pai biológico, com o caudilho do Partido Nacional, Aparicio Saravia, chefe de duas insurreições, na segunda das quais foi ferido por uma bala na Batalha de Masoller que, em poucos dias, tirou-lhe a vida (setembro de 1904). Quase exatamente ao mesmo tempo em que Emir Rodríguez Monegal teve essa revelação, em 1942, seu tio José Monegal publicou um volumoso tomo encomiástico sobre o caudilho fronteiriço: Vida de Aparicio Saravia:

[...] meu tio Pepe me dedicou um exemplar muito carinhosamente. Eu era, então, um adolescente muito metido em Proust e Joyce, em Kafka e Borges; agradeci o livro, dei uma folheada, mas não o li nem pensei que pudesse lê-lo algum dia. [...] Eu era socialista e acreditava (acredito ainda) que uma solução para nossos países estava nos caudilhos, da forma que fosse. Uns anos depois me veria obrigado a reconsiderar o problema. (MONEGAL, 1989, p. 185). 
Primeiro a resistência em reverenciar o totem familiar e o ancestral do pai assassinado pelo irmão de quem contribuíra para o seu monumento, sob a forma de louvor biográfico. ${ }^{4}$ Depois, nos anos adultos, Rodríguez Monegal chegaria a reconsiderar aquela atitude. Borges seria o responsável pela mudança.

Borges viria a ocupar o lugar daquele pai, quando Rodríguez Monegal descobre a obsessão do argentino pela figura do caudilho e seu tempo em numerosos contos e poemas de diferentes épocas. Entre eles, "A outra morte", onde aparece como personagem circunstancial "meu amigo Emir Rodríguez Monegal", esse parente distante de Saravia.

Isto Borges não poderia suspeitar, mas o personagem-crítico, sim, podia especular (ou fantasiar) sobre as razões de sua intervenção - como o fez num artigo, "As vidas e as mortes de Aparicio Saravia" para fazer de sua própria identidade e de sua própria história familiar objeto precioso de matéria literária. Uma história de intrigas, abjeções, crimes, triângulos amorosos, valentias e covardias que, além disso, transcorre perto da fronteira com o Brasil. Como em um conto de Borges.

Zoraida Nebot, que contraiu casamento com Rodríguez Monegal em 1950, a quem entrevistei em 1992 em seu domicílio, na cidade de Maldonado, disse que, um dia antes de casar-se, Emir contou-lhe esta história, sem grandes detalhes, e que nunca mais voltou a falar do assunto. Àquela altura, conversei em várias oportunidades, e separadamente, com Manuel A. Clips, Idea Vilariño e Mario Benedetti, codiretores com Rodríguez Monegal da revista Número. Cada um deles sabia algo dessa história, não pelo testemunho do implicado, mas através de Zoraida Nebot. Em outras palavras, uma versão uruguaia de Rashomon.

Em uma palestra que se mantém inédita, e que foi lida em um congresso sobre Borges e o Uruguai, em agosto de 1999, Joaquín Rodríguez Nebot, filho de Rodríguez Monegal, comunicou que em "um quarto de hotel em Buenos Aires", em 1975, seu "pai se atreve a falar do inominável. Fica-me a vaga lembrança da lágrima rolando pela face, a dor e o sofrimento desse fato remoto que marcou com seu signo, com seu estigma, sua existência muito antes de tornar-se homem". ${ }^{5}$ De uns versos de Borges do poema "Un lector", em Elogio de la sombra (1969), Rodríguez Monegal tomou o título geral de suas memórias:

...el olvido

es una de las formas de la memória, su vago sótano,

la otra cara secreta de la moneda

O duplo fundo, o "vago sótão" no qual os mais velhos depositaram tanto silêncio e tanta morte, somente poderia ser resolvido por Rodríguez Monegal à beira de seu próprio fim. Antes, laboriosamente, trataria de encontrar outro pai, "a outra cara secreta da moeda", quem lhe revelara a possibilidade de fazer o que queria: literatura marginal à altura da admirada metrópole. Com seu extenso livro Jorge Luis Borges: a literary biography, escrito em inglês e publicado em 1978, viria a fechar sobre si mesmo o círculo daquilo que entendeu como o conflito fundador da identidade do autor de El Aleph: o bilinguismo.

Esta foi a panaceia: narrar uma história de vida e de literatura na língua que, desde muito jovem, defendeu como a chave maior da alta cultura. Borges, que Rodríguez Monegal assinala como o maior escritor em língua espanhola, justamente pela mediação da língua inglesa tinha conseguido elevar a língua espanhola a um degrau somente alcançado, antes, no Século de Ouro, com Cervantes, Góngora ou Quevedo (MONEGAL, 1978). ${ }^{6}$

Esse encontro é resumido no último e extenso livro sobre Borges, que sobreviveu ao biógrafo e que, poucos dias antes da anunciada morte do crítico, agradeceu publicamente esse livro como um ato de amizade, ainda que não o tenha admitido como "uma biografia do que havia ocorrido, mas do que podia ter ocorrido". C Com essa chave hermenêutica Rodríguez Monegal pôde construir a ponte entre seu pai simbólico e o outro, o matador do pai biológico, a quem Borges vem substituir. ${ }^{8}$ Uma pergunta de Juan Gustavo Cobo Borda desencadeia uma autoanálise que, de maneira mais estilizada, repetiria em Las formas de la memória: 
- [...] Por que o Sr. apareceu como personagem ou menção, em um conto de Borges?

- [...] O conto chamava-se "A redenção", a primeira vez em que foi publicado, no ano de 1948, em La Nación de Buenos Aires, e eu fui a primeira pessoa surpreendida porque comprava todos os domingos $\mathrm{La} \mathrm{Na}$ ción e seu suplemento cultural. Assim, fui buscar o jornal e enquanto o folheava vi um conto de Borges. Já em minha casa comecei a lê-lo e, de repente, na primeira coluna, salta o nome de Emir Rodríguez Monegal. Fiquei muito nervoso, pois se havia algo que eu não esperava era ler-me como personagem. [...] Tive a ideia, isto sim, de que Borges havia usado meu nome como um toque de verossimilhança quase secreta, porque era óbvio que em 1948 ou 49, quando saiu o conto, primeiro na revista e, depois, no livro El Aleph, ninguém sabia quem eu era, mas ele poderia dizer, bem... o nome de Rodríguez Monegal justifica-se porque [...] nasceu no mesmo povoado do herói gaúcho que serve de pretexto para o conto. Aparicio Saravia era de Cerro Largo, Melo era o lugar onde tinha seus quartéis e, então, o nome de uma pessoa que havia nascido em Melo e que era de uma família de Melo era uma garantia de verossimilhança, ainda que uma verossimilhança somente possa ser verificada em minha casa, não? Mas Borges tem essas satisfações secretas. [...] [Em] um encontro com Borges em Nova Iorque, perguntei-lhe se havia lido o livro de Manuel Gálvez [ $\mathrm{Vi}$ da de Aparicio Saravia. Buenos Aires, 1942] para o conto [...]. Ele me disse: "Não, não o conheço". E o livro de meu tio Pepe Monegal [Vida de Aparicio Saravia. Montevidéu, 1942] não o conhece? "Não, não, eu não li o livro de seu tio; além disso, não conheci seu tio. Conheci o seu outro tio". Deu-me uma sensação de vertigem, porque eu tinha outro tio que era ainda mais desconhecido do que Pepe Monegal, mas, apesar de ser tão desconhecido, era conhecido de Borges: Casiano Monegal. (BORDA, 1998, p. 73-74).

A curiosidade do interlocutor colombiano, inocente de toda informação biográfica remota de seu entrevistado, não se deteve nesse ponto. Ao contrário, continuou perguntando sobre a família. $\mathrm{O}$ entrevistado, por sua vez, acrescentou detalhes sobre uns e outros, para concluir: "tive uma dupla origem, que era basicamente espanhola, porque os Monegal são catalães e vascos e, pela parte de meu avó Rodríguez éramos, na família, galegos e andaluzes".

Diante do fato de que a transcrição de Cobo Borda é fiel - ao extremo de reproduzir as dramatizações orais, as redundâncias e até as interjeições -, não se incorreria em uma sobreinterpretação desse "romance familiar do neurótico" (Freud dixit) caso se observasse que o entrevistado começa por mencionar os Monegal, aos quais alude no presente do indicativo do verbo ser ("são"); passa, depois, aos Rodríguez que figuram no pretérito imperfeito (“éramos”); mas, em seguida, vacila e substitui o sujeito, ou melhor, multiplica-o: "a família”. Outra opção seria trocar o lapsus linguae restituindo o verbo ao singular, com o qual se forjaria um verossímil e excludente lapsus calami: "A família Rodríguez era de galegos e andaluzes".

No artigo que serve de apêndice às memórias, "As vidas e as mortes de Aparicio Saravia", depois de comentar com prazer e orgulho os episódios que articulam "La otra muerte" com as declarações privadas de Borges, para melhor reconhecimento de sua família (seus tios Pepe e Cacho e, certamente, ele mesmo), a curiosidade do vigilante crítico parece saciar-se. Isto ocorre quando Borges informa - e isto não poderia senão satisfazer Rodríguez Monegal - que a história que inspirara o conto tinha sido contada a ele por seu tio Luis Melián Lafinur, que era uruguaio. "Foi a clara resposta”, diz Rodríguez Monegal. Era a saída para o seu conflito. Por isso, somente após ter aprendido pela boca de seu pai-professor, pôde emitir o seguinte julgamento: "creio que há, aqui, uma lição para todo biógrafo. As fontes escritas que nos preocupam tanto, por mais impecáveis que pareçam ao investigador, não bastam” (MONEGAL, 1989, p. 17). Sempre há um "sótão vazio" e nele, às vezes, se sobrepõem as distintas formas da morte:

Emir vai a Melo procurar respostas, talvez. Em uma suposta bebedeira, agride seu tio Cacho - o suposto assassino. Ali é resgatado por seu tio Pepe e devolvido a Montevidéu, com um quadro de surmenage. Uma elegante forma para nomear a psicose aguda. É aqui que meu pai morre pela primeira vez. A revelação abominável de ser um bastardo acompanhou-o por toda a vida. É nesse momento em que deixará de ser a criança protegida para tornar-se um homem. Como não pode encarar nem o punhal nem o revólver, usará a caneta como fonte de disparos, juízos e mortes literárias. (NEBOT, 1999). 
Agressividade, perturbação e busca de um lugar no universo das letras - contra o vento e a maré de outros - tinham que encontrar um contrapeso na defesa sem limite de suas radicais certezas. Em todo terreno e diante de qualquer ataque, até mesmo em quase toda incursão sobre sua obra, traduziu a defesa de seu pai literário, o qual preferiu ver como um gênio nunca suficientemente reconhecido, um perseguido. Toda escrita é autobiográfica, teria declarado em uma entrevista dos últimos anos. Por isso, escrevia seus livros. "Salvo Borges, com quem já havia aprendido a desconfiança, eu não me dava conta de que estava escrevendo fragmentos de minha biografia”. Após esta confissão e diante do pedido de esclarecimento do atônito jornalista, acrescenta:

Em meu livro sobre [Andrés] Bello, por exemplo, que escrevi entre os anos cinquenta e cinquenta e seis, era minha intenção explicar como um homem totalmente independente em suas ideias sofre a perseguição de todos porque não adere ao ponto de vista conhecido... É a história de minha vida. (CAPARRÓS, 1995, p. 29).

Se a biografia de Borges não resiste de modo algum à exclusão desse padrão autobiográfico, menos se poderia dizer do ensaio sobre Roberto de las Carreras (Montevidéu, 1873-1963), que certamente não evoca na confessional entrevista, talvez por considerá-lo uma peça menor ou menos visível no quadro de recepção de sua obra.

Escandaloso dandy do Novecentos, esse poeta e liberal pertinaz nasceu da união irregular entre a rica e libertina Clara García de Zúñiga e o não menos poderoso (e talvez não menos licencioso) Ernesto de las Carreras, quem - segundo Rodríguez Monegal - "abandonou o menino em seu destino de bastardo e somente preocupou-se (quando já havia crescido) em dar-lhe alguma lição de moral" (MONEGAL, 1969, p. 11). ' Sua leitura de Roberto de las Carreras, sem desconsiderar "o meio [que] influenciou decisivamente a forma de seu destino", nega o privilégio desse campo para a explicação cabal de um autor, entretanto, adotada por "sociólogos populares dos últimos tempos" (MONEGAL, 1969, p. 9). Na verdade, o uso da categoria "sociólogo", no plural, é uma maneira simultânea de aludir e ignorar a Ángel Rama, que, já no apogeu de seu exercício crítico no semanário Marcha, havia publicado um longo artigo, depois reconhecido - com modificações - como prólogo de uma antologia do autor maldito (RAMA, 1967).

Rama prefere examinar o meio social, econômico e cultural do Novecentos rioplatense, mas não descarta o peso dos fatores biopsíquicos na personalidade da mãe do poeta, e no poeta mesmo, nem esquece o episódio traumático de sua condição de filho bastardo. Contudo, este dado é, apenas, um fator a mais em um vasto friso. A aceitação e até a encenação teatral dessa ilegitimidade é interpretada por Rama como uma "audaz resolução" do homem sofredor - Carreras -, que manifestava, assim, um "profundo e desolado amor por sua mãe", a quem quis desagravar frente à filisteia moral burguesa, ocupando seu lugar (RAMA, 1967, p. 12 e 16).

Nem um só adjetivo forte acompanha a palavra "bastardo" no longo texto de Rama nem - assombrosamente - uma informação precisa sequer oferece sobre o pai: "Como no começo de todo o homem, no de Roberto de las Carreras está sua mãe", inicia a passagem biográfica e, depois, vai acrescentando informações nada relevantes sobre Clara García de Zúñiga. Também se esquece de que alguém - nada menos do que alguém que havia sido ministro de Estado e homem de fortuna - participou na procriação do garoto e até deu-lhe seu sobrenome. Novamente, e em outro registro sob outras mãos, o pai é um significante vazio.

A interpretação monegaliana do indivíduo e da obra de Roberto de las Carreras concentra-se no problema da origem e, à medida que comenta outros textos ou episódios, povoa essa origem com adjetivos. São estes tão mais obsessivos e perturbadores quanto o passeio por esse ensaio de tão poucas páginas: "lamentável condição de bastardo"; "o estigma de bastardo"; "seu horrível ressentimento de bastardo" (MONEGAL, 1969, p. 15 et passim). Carreras perdeu a razão em 1913. Aqueles anos, que o poeta decadentista nomeou "de escândalo e glória", para Rodríguez Monegal "são os anos realmente negros, os anos da grande humilhação cotidiana, do castigo infringido pelo mais implacável carrasco: sua própria consciência” (MONEGAL, 1969, p. 24-25). 
Em um texto de 1983, Rodríguez Monegal apontou que "um crítico perspicaz já havia descoberto que, em Graciliano Ramos, 'o menino é tudo"'. Como Wordsworth - que havia cunhado em um famoso poema a fórmula: the Child is father of the Man -, as raízes mais profundas da criação literária de Graciliano Ramos estavam nessa infância atroz (MONEGAL, 1983, p. 40). O menino é o pai do homem, disse e repetiu em diversos textos. Até o término de sua vida, Rodríguez Monegal parece ter dialogado com este verso do romântico inglês e com a lição que Borges estampou em outros poemas, estreitamente aparentados com "Un lector". Como em "1964": "...no basta ser valiente / para aprender el arte del olvido". E, mais ainda, talvez tenha encontrado temor e alívio no último terceto de "Edipo y el enigma", outro poema borgiano: "Nos aniquilaría ver la ingente / forma de nuestro ser; piadosamente / Dios nos depara sucesión y olvido". ${ }^{10}$

\section{Descobrir o Brasil}

Depois de passar por Melo, Emir Rodríguez Monegal entrou no Brasil pela fronteira seca do Nordeste. Não recordo a data com precisão, mas sei que era pequeno, não tinha mais do que oito anos, e que estava sob os cuidados de seu tio José, visto que seus pais já estavam em outro destino: Porto Alegre. Ali teve um rápido contato com a língua que havia sido a dos Pereyra, um ramo um tanto distante de sua família materna. Mas, o verdadeiro descobrimento desse país feérico, de acordo com as reconstruções que faz por meio das recordações de Manuel Rodríguez, ocorreu no inverno de 1930, quando cruzou o Atlântico, com sua família, em um navio que atracou em São Paulo, depois em Santos e, por fim, chegou ao Rio de Janeiro.

Este seria seu lar por alguns meses até o retorno a Montevidéu, uma vez que seu pai não conseguira o emprego que esperava. O Brasil deslumbrou-o pelo clima, pela natureza exuberante - em especial, as paisagens do Rio que descreve desde o transatlântico -, suas árvores gigantescas, o inconfundível cheiro do café, o sabor da feijoada e "das mil e uma frutas locais" (MONEGAL, 1989, p. 118); mas, também o atormentaram as multidões, o calor, os insetos que o importunavam com uma agressividade desconhecida em Montevidéu.

Cinco anos depois, seus pais voltariam ao Rio. Desta vez, permaneceriam dois anos, quando Rodríguez Monegal já havia entrado na adolescência. Algumas coisas apenas mudariam de cenário: continuaria frequentando o Lycée Français, como fazia em Montevidéu, e as funções cinematográficas, já agora, na Cinelândia. Outras aventuras ser-lhe-iam apresentadas, considerando-se a distância cronológica entre esta e a primeira viagem e a distância cultural com Montevidéu.

Para começar, ante a afirmação de um garoto argentino de que "os brasileiros eram uns macacos" (MONEGAL, 1989, p. 147) sentiu-se ferido, porque afirmava sentir-se como um brasileiro. O Rio deu-lhe mais liberdade: a de transitar pelos mais brilhantes e obscuros rincóes da cidade; a de entregarse aos prazeres do corpo em sua interminável sucessão de praias; a de conhecer o esplendor do carnaval. Ali também disse ter adquirido a consciência política do mundo e a repulsa aos fascismos: "eram os tempos do Estado Novo" (MONEGAL, 1989, p. 135). Ali aprendeu sua quarta língua e começou a experimentar o gosto pela literatura brasileira que, ao final da vida, decidiu eleger como ponto de partida para situar o seu descobrimento da América Latina:

Nessa época, mamãe começou a interessar-se pelos novos romancistas do Nordeste. Jorge Amado, Lins do Rego, Graciliano Ramos, e suas obras começaram a circular pela casa. Li $O$ moleque Ricardo, do qual gostei muito, e alguns dos primeiros de Amado (Cacau, acho) que me pareceu mais dogmático. Graciliano Ramos eu voltaria a ler mais tarde em Montevidéu, a partir de Angústia. Contudo, essas leituras, por mais imperfeitas que fossem, despertaram-me o gosto pela nova literatura e prepararam-me para descobrir, mais tarde, os romancistas hispano-americanos que estavam mais ou menos na mesma linha. Isso não quer dizer que eu lia com muita profundidade. [...] Mas, acredito que dessa maneira, meio distraída, comecei a formar-me como crítico. É sempre algo agradável para mim pensar que foi a nova literatura brasileira que me colocou em um bom caminho. A ela devo o estímulo da modernidade. (MONEGAL, 1989, p. 156). 
Esses primeiros contatos foram, de fato, os que o colocaram entre os primeiros leitores de sua geração - em toda a América Hispânica - genuinamente interessados pela cultura brasileira. Se no subtexto o autobiografismo esteve sempre presente nos escritos de Rodríguez Monegal, esta tendência - que tão irritantemente o faria parecer com Rama - estendeu-se, na última época, por quase todas as suas contribuições. Isso explica a semelhança de duas passagens construídas, paralelamente, em seu artigo "El olvidado ultraísmo uruguayo" (1982) e nas memórias que escreveu, a todo vapor, três anos depois. Trata-se da evocação de Ildefonso Pereda Valdés, já distante de seu juvenil e ativo papel de vanguardista, agora convertido em um senhor sereno, professor de Literatura no Ensino Secundário que, sem abandonar a poesia havia se voltado, por esses anos, aos estudos de antropologia cultural, capitalizando seu conhecimento (e seus contatos) no Brasil e no Rio da Prata, para aprofundar suas investigações sobre o negro na cultura uruguaia. Pereda era amigo de José Monegal. No verão de 1935, antes de sair para o Rio de Janeiro, tio e sobrinho fizeram-lhe uma visita, que o crítico marca retrospectivamente como o início de sua curiosidade pelas letras brasileiras:

[...] recordo que fiquei deslumbrado com a biblioteca de Ildefonso que [...] ocupava um quarto inteiro de seu maravilhoso apartamento. Era clara, bem organizada e cheia de quadros da vanguarda uruguaia, argentina e brasileira. Por sua origem, Ildefonso tinha raízes no Brasil; seu Valdés era português e não espanhol. Enquanto os grandes conversavam, eu passava e repassava o olhar sobre tantos livros. Acredito que foi ali quando, pela primeira vez, vi as obras de Mário de Andrade e, sobretudo, Macunaíma, que encontraria uns quinze anos mais tarde em uma velha livraria de Montevidéu e que era, então, a única edição. (MONEGAL, 1982, p. 261).

A versão de Las formas de la memoria... guarda uma variante significativa em relação ao acervo bibliográfico do anfitrião e, também, sobre sua cortesia especial com o visitante adolescente:

Mostrou-me com orgulho sua biblioteca de autores brasileiros (estava realmente atualizada) e sua coleção de textos afro-uruguaios. Era quase o único, então, a dedicar-se ao estudo da influência da cultura africana. (MONEGAL, 1989, p. 158).

Antes de sair de Montevidéu, então, e em seu regresso dois anos mais tarde, o contato com Pereda Valdés colocou Monegal no caminho seguro de um conhecimento atualizado da cultura brasileira. Além disso, em 1942 realizou estágio docente para habilitar-se como professor de Literatura na Educação Média com aquele senhor de modos refinados e ar distraído. Mas o abrupto desaparecimento de Emir Rodríguez Monegal privou-nos dessa significativa parte do relato da construção de si mesmo, como ativo intelectual que contribuiu com suas intervençôes, em anos cruciais, para a mudança do rumo da literatura latinoamericana.

Tradução: Maira A. Pandolfi Revisão técnica e edição: Maria Aparecida Rezende Mota

\footnotetext{
Notas

${ }^{1}$ Rodríguez Monegal não conhecia detalhadamente a história da família. Na página 100 de suas memórias diz que os "Monegal haviam chegado ao Uruguai por volta da terceira ou quarta década do século XIX". Segundo o Diccionario biográfico de Maldonado, de Maria A. Díaz de Guerra (Montevidéu, IMCO, 1974), os Monegal aparecem no então povoado de Maldonado, no leste uruguaio, ao final do século XVIII. Alexo (ou Alejos) Monegal, nascido em Bagá (Catalunha), casa-se nesse povoado uruguaio, em 1785, com Joaquina Machado (natural do Rio Grande, Brasil). O casal tem seis filhos, o segundo deles (Alejos Justo, nascido no dia 19 de julho de 1788) casa-se em Maldonado, no dia 24 de abril de 1809, com Catalina Felipa Chalar. Desse casamento nascem sete filhos. O último, Pedro Liberato Monegal, nascido na mesma localidade no dia 23 de julho de 1819, casa-se em 1848 com Antonia Labrea, natural de San Carlos, localidade próxima a Maldonado. Dessa união, nascem cinco filhos, o primeiro deles chamou-se Cándido (nascido em Villa Artigas, posteriormente Rio Branco,
} 
no limite da fronteira com o Brasil, em 1854. As pesquisas que realizamos no Arquivo da Intendência Municipal de Cerro Largo, na cidade de Melo, em 1985 e 1989-90 - com a imprescindível contribuição do professor Víctor H. Ganello -, levaram-nos a apurar que Cándido Monegal casou-se em Melo no dia 13 de agosto de 1881 com Paula Sorondo. Nessa mesma vila, onde Cándido morreu em 3 de março de 1941, nasceram do matrimônio com Paula os seguintes filhos: Cándido (1882-1888); Casiano (1885-1944), poeta e jornalista e, segundo sugere Rodríguez Monegal em suas memórias, assassino de Héctor F. Suárez; Zulmira (1888, falecida no dia 18 de outubro desse ano, segundo consta na certidão de óbito "de siete meses, de sarampión”); Maria Elena (1888, falecida “de siete meses de sarampión”, gêmea da anterior); Angelina (189027/3/1893); José (1892-1968), poeta, narrador, autor de teatro, jornalista com longo desempenho no jornal de seu pai e no diário El Dia, de Montevidéu; Guadiela (desconheço dados precisos); Nilza (desconheço dados precisos); Hilda Gertrudis (24/3/1899 -Montevidéu, 1950), mãe de Emir e Miguel Angel (1890-27/3/1893).

${ }^{2}$ Para não ir mais longe e evitar referências concretas, cf. Rocca, 1992.

${ }^{3}$ Referente aos naturais da República Oriental do Uruguai (nota do revisor).

${ }^{4}$ José Monegal escreveu contos e foi historiador oficial do Partido Blanco ao longo das décadas de 1940 e 1950 . Não escreveu apenas o volume sobre Saravia, mas uma longa série de artigos no diário El País que reuniu, parcialmente, em seu Esquema de la historia del Partido Nacional (Montevidéu, Ciudadela, 1959). Sobre seu irmão Casiano, não há referências acerca de sua filiação política. Informações sobre os dois encontram-se em Nuevo diccionario de literatura uruguaya. Montevidéu: Banda Oriental, 2001. T. II, p. 87-88. Organizei a bibliografia completa, ativa e passiva, de José Monegal no Apêndice da Narrativa rural en la región entre los años veinte y cincuenta. Actas de las Jornadas. Montevidéu, Universidad de la República, 2002.

5 "Borges y Emir: un cuento a desarrollar”, Joaquín Rodríguez Nebot (1999). Devo a Rodríguez Nebot o amistoso gesto de entregar-me uma cópia de sua palestra - original datilografado em cinco laudas, com espaço e meio. O texto não está incluído nos Anais do congresso, que saíram em 2000, sob a coordenação de Sylvia Lago e Alicia Torres (Borges y el Uruguay. Montevidéu, Universidad de la República).

${ }^{6}$ Visto dessa maneira, como foi comentado por Cecília Molinari Lean-Cole, o último dos três conceitos tomados de Freud e de Lacan - o triângulo edípico, a contemplação da cena primária e o estágio do espelho - segundo a interpretação de Monegal sobre a formação da identidade de Borges, poderia ter envolvido o próprio Borges? (" ¿La memória de Borges? Recuerdos de infancia en Borges: una biografia literaria”, Montevidéu, FHCE, 2003. Inédito).

7 “Borges y Emir”, em Jaque, Montevidéu, no 99, 7 de novembro de 1985, p. 34. Texto enviado especialmente por Borges para ser lido na última conferência que Rodríguez Monegal pronunciou em Montevidéu. Nele se lê "Buenos Aires, 22 de octubre de 1985". Recolhido em La desconstrucción..., 1987.

${ }^{8}$ Rodríguez Monegal desenvolveu uma interpretação semelhante sobre Leopoldo Lugones como pai simbólico de Horacio Quiroga, em seu livro El desterrado. Vida y obra de Horacio Quiroga (1968).

${ }^{9}$ A versão original desse ensaio apareceu em Número, Montevidéu, no 3-4, maio de 1964, p. 90-108. O texto final não registra variantes significativas.

${ }^{10}$ O filho de Rodríguez Monegal recorda um apaixonado comentário de seu pai sobre Crónica de uma muerte anunciada (1981), de Gabriel García Márquez, pouco tempo após a publicação desse romance.

\section{Referências bibliográficas}

BORDA, Juan Gustavo Cobo. Diálogo de ultratumba con Emir Rodríguez Monegal. Revista de la Universidad de Antioquia, Antioquia, v. LVI, no 213, jul.-set. 1988, p. 71-82.

BORGES, Jorge Luis. Prosa narrativa. Barcelona: Bruguera, 1982. 2 v.

Obra poética, 1923-1976. Buenos Aires: Emecé, 1979.

CAPARRÓS, Martín. Hace diez años. Con Rodríguez Monegal. Relaciones, Montevidéu, noํ 130, março 1995, p. 29-31.

COTELO, Ruben. Emir Rodríguez Monegal: el olvido es una forma de la memoria. Jaque, Montevidéu, no 99, 7/2/1985, p. 34-37.

FREUD, Sigmund. Introducción al psicoanálisis. Trad. Luis López-Ballesteros y de Torres. Madri: Alianza, 1968.

LEJEUNE, Philippe. Le pacte autobiographique. Paris: Editions du Seuil, 1975.

MONEGAL, José. Vida de Aparicio Saravia. Montevidéu: A. Monteverde y Cía, 1942.

MONEGAL, Emir Rodríguez. El autor de Rashomon. Marcha, Montevidéu, no 745, 17/12/1954, p. 15. [Resenha de Rashomon, de Ryunosuke Akutagawa]. . El desterrado. Vida y obra de Horacio Quiroga. Buenos Aires: Losada, 1968. 
. Sexo y poesía en el Novecientos. Montevidéu: Alfa, 1969.

Borges / Mário de Andrade: um diálogo dos anos vinte. São Paulo: Perspectiva, 1978.

. Graciliano Ramos y el regionalismo nordestino. Revista de la UNAM, México, Nueva época, v. XXXIX, no 30 , outubro 1983 , p. 34-41.

El olvidado ultraísmo uruguayo. Revista Iberoamericana, Pittsburgh, no 118-119, janeiro-junho 1982, p. 258-274. [Recolhido em La obra crítica de Emir Rodríguez Monegal. Montevidéu: Ediciones de la Plaza, p. 85102, 1989. Coletânea e notas de Pablo Rocca e Homero Alsina Thevenet].

Borges / de Man/ Derrida/ Bloom: La desconstrucción avant et aprés la lettre. In: Diseminario. La desconstrucción, otro descubrimiento de América. Montevidéu: XYZ Ed., 1987, p. 119-123.

. Las formas de la memoria, Los magos. México: Vuelta, 1989.

NEBOT, Joaquín Rodríguez. Borges y Emir: un cuento a desarrollar. [Comunicação lida no Congresso "Borges y el Uruguay”, Montevidéu, Faculdade de Humanidades e Ciências da Educação, Universidad de la República, 11 de agosto de 1999. Manuscrito].

RAMA, Ángel. Tierra sin mapa. Montevidéu: Cooperativa Asir, 1960.

. Prólogo. In: CARRERAS, Roberto de las. Psalmo a Venus Cavalieri y otras prosas. Montevidéu: Arca, 1967, p. 7-46.

ROCCA, Pablo. 35 años en Marcha (crítica y literatura en Marcha y en el Uruguay 1939-1974). Montevidéu: División Cultura de la IMM, 1992.

\title{
RESUMO
}

Um homem jovem, de uma família da classe média, converte-se em intelectual. Esse homem ocupa um espaço central na cultura literária do seu país (Uruguai) e, aos poucos, na América Latina. Mas, ele carrega consigo um drama pessoal, uma marca de origem, que sempre procura encobrir e que, no entanto, sua própria escrita acaba por desvendar. Este artigo explora a(s) história(s) e os caminhos de Emir Rodríguez Monegal (1921-1985), um dos principais especialistas em literatura latino-americana no século XX. Em especial, Monegal foi um leitor privilegiado, desde os anos 1940, da obra de Jorge Luis Borges, cuja escrita foi fundamental, também, para que o crítico pudesse compreender-se a si mesmo. Palavras-chave: Emir Rodriguez Monegal, biografía, Literatura, História.

\begin{abstract}
A young man from a middle-class family, becomes an intellectual. This man occupies a central place in the literary culture of his country (Uruguay) and, gradually, in Latin America. But he carries with him a personal drama, a mark of origin, who always tries to hide and that, however, his own writing reveals. This article explores the history (or the stories) and paths of Emir Rodriguez Monegal (1921-1985), a leading expert on Latin American literature in the twentieth century. In particular, Monegal was a privileged reader, since the 40's, of Jorge Luis Borges works, whose writing was crucial to the self-understanding of Monegal's own personality.

Keywords: Emir Rodríguez Monegal, biography, Literature, History.
\end{abstract}

